\title{
Pengaruh Model Pembelajaran Kooperatif Tipe Picture And Picture Terhadap Minat Belajar Dan Hasil Belajar IPS Pada Peserta Didik Kelas VII Sekolah Menengah Pertama Kesuma Sari Denpasar
}

\author{
Ni Luh Ayu Wahyuni ${ }^{1}$, Nengah Bawa Atmaja ${ }^{2}$, I Wayan Kertih ${ }^{3}$ \\ Prodi Pendidikan IPS Universitas Pendidikan Ganesha Singaraja \\ e-mail: ayuwahyuni220593@gmail.com ${ }^{1}$
}

\begin{abstract}
Abstrak
Tujuan penelitian ini untuk mengetahui (1) pengaruh model pembelajaran kooperatif tipe picture and picture terhadap hasil belajar IPS. (2) pengaruh model pembelajaran kooperatif tipe picture and picture terhadap minat belajar (3) pengaruh antara model pembelajaran kooperatif tipe picture and picture terhadap minat belajar dan hasil. Penelitian menggunakan metode Quasi Eksperimen dan menggunakan desain penelitian the posttest only control group design. Populasi penelitian ini adalah 3 kelas VII dengan sampel kelas VII1 dan VII2 yang ditentukan dengan teknik Random Sampling.. Hasil penelitian menunjukkan bahwa (1) ada pengaruh model pembelajaran kooperatif tipe picture and picture terhadap hasil belajar IPS (sig. 0,000< $0,05)$. (2) ada pengaruh model pembelajaran kooperatif tipe picture and picture terhadap minat belajar IPS (sig. 0,009<0,05), (3) ada pengaruh antara model pembelajaran kooperatif tipe picture and picture terhadap minat belajar dan hasil belajar (sig. $0,000<0,05$ )

Kata Kunci: picture and picture, minat belajar, hasil belajar

\section{Abstract}

The aimed of this research is to understand (1) the effect of model of cooperative learning of "picture and picture" type in the learning results of IPS. (2) the effect of cooperative learning model "picture and picture" type of learning interest (3) the effect between cooperative learning model of "picture and picture" type of learning interest and learning results. The research used the Quasi experiment method and the Posttest only control group design. The population of this research are 3 classes of VII grade students with VII1 and VII2 classes as samples determined by the Random Sampling technique. The results showed that (1) there was an effect on the cooperative learning model of "picture and picture" type towards the learning results of IPS (sig. 0,000<0,05), (2) There was effect on cooperative learning "picture and picture" type of learning interests IPS (sig. 0,009<0,05), (3) there was an effect between the model of cooperative learning picture and picture type of learning interest and learning outcomes (sig. 0,000<0,05)

Keywords: picture and picture, learning interests, learning outcomes
\end{abstract}

\section{PENDAHULUAN}

Proses pendidikan merupakan suatu sistem yang terdiri dari input, proses dan output. Input yang dimaksud adalah peserta didik yang akan melaksanakan aktivitas belajar, proses merupakan kegiatan dari belajar mengajar sedangkan output merupakan hasil dari proses yang akan dilaksanakan. Dari pelaksanaan proses pendidikan tersebut diharapkan dapat menghasilkan output yang berkualitas dan berdaya saing yang tinggi yan diharapkan menghadapi persaingan di era globalisasi. Sebagai salah satu upaya, pendidikan ini harus dilaksanakan sebaik mungkin. Dalam suatu pendidikan digunakan evaluasi untuk memantau perkembangan pendidikan. Evaluasi dilakukan dalam rangka pengendalian mutu pendidikan secara nasional sebagai bentuk akuntabilitas penyelenggara pendidikan kepada pihak-pihak yang berkepentingan. 
Keberhasilan pencapaian suatu tujuan pendidikan di sekolah tergantung pada keberhasilan proses belajar peserta didik. Belajar merupakan proses perubahan tingkah laku melalui penyelesaian masalah yang telah diberikan melalui proses eksplorasi, elaborasi, dan konfirmasi sehingga adanya proses penemuan dalam kegiatan pembelajaran. Pada dasarnya peningkatan kualitas pendidikan dilihat dari kemampuan guru dalam melakukan proses belajar mengajar di kelas. Guru yang mampu menciptakan suasana pembelajaran yang menyenangkanbagi siswa adalah guru yang memiliki kompetensi yang memadai untuk membentuk individu-individu baru yang cerdas. Susanto (2012:185) mengatakan bahwa pembelajaran merupakan komunikasi dua arah, mengajar dilakukan oleh pihak guru sebagai pendidik, sedangkan belajar dilakukan oleh siswa. Isjoni (2010:11) mengungkapkan bahwa pembelajaran pada dasarnya merupakan upaya yang dilakukan pendidik untuk membantu siswa melakukan kegiatan belajar. Tujuan pembelajaran adalah terwujudnya efisiensi dan efektifitas kegiatan belajar yang dilakukan siswa.

Belajar pada hakikatnya merupakan suatu proses yang ditandai dengan adanya perubahan diri seseorang (Trianto, 2009:9). Menurut R. Gagne, 1989 (dalam susanto, 2012:1) belajar dapat didefinisikan sebagai suatu proses dimana suatu organisme berubah perilakunya sebagai akibat pengalaman. Menurut Bower dan Hilgard (dalam Suwatra, dkk. 2007:2) "belajar mengacu pada perubahan perilaku atau potensi individu sebagai hasil pengalaman dan perubahan tersebut tidak disebabkan oleh instink, kematangan atau kelelahan dan kebiasaan". Berdasarkan pandangan diatas dapat disimpulkan bahwa belajar merupakan suatu kegiatan yang dilakukan seseorang untuk memperoleh konsep, pemahaman, dan pengetahuan yang baru.

Pendidikan IPS yang berkualitas tentu akan menghasilkan generasi penerus yang berbobot untuk pengembangan Negara. Namun dalam kenyatannya, ada sebagian siswa yang kurang memiliki minat belajar dalam pembelajaran IPS karena kurang senang dengan penggunaan metode dalam proses kegiatan pembelajaran. Hal ini disebabkan karena metode yang dipergunakan dalam setiap kegiatan pembelajaran selalu sama tanpa disertai dengan model pembelajaran yang sesuai. Uraian tersebut didukung oleh hasil observasi dengan beberapa guru mata pelajaran IPS yang terungkap bahwa guru dominan masih menggunakan model pengelolaan kelas yang bersiat konvensional.

Proses pembelajaran berperan penting dalam meningkatkan minat belajar siswa. Minat tidak akan ada secara langsung melainkan timbul akibat dari partisipasi dan kebiasaan saat belajar. Seseorang yang memiliki minat pada suatu mata pelajaran cenderung hasil belajar yang diperoleh lebih baik. Menurut Susanto (2012:57) minat merupakan kecenderungan jiwa seseorang terhadap sesuatu objek, biasanya disertai dengan perasaan senag, karena itu merasa ada kepentingan sesuatu. Sedangkan menurut Bernard dalam Susanto (2012:57) menyatakan bahwa minat timbul tidak secara tiba-tiba atau spontan, melainkan timbul akibat partisipasi, pengalaman, kebiasaan waktu belajar atau bekerja.

Dalam proses pembelajaran hasil belajar juga perlu ditingkatkan. Hasil belajar merupakan prestasi yang dicapai peserta didik dalam setiap proses kegiatan belajar mengajar. Menurut Marheni (2012:9) hasil belajar adalah perubahan yang mengakibatkan manusia berubah dalam sikap dan tingkah lakunya.

Berdasarkan uraian yang telah dikemukakan di atas, maka peneliti berkeinginan untuk mengadakan suatu penelitian dengan judul "Pengaruh Model Pembelajaran Kooperatif Tipe Picture And Picture Terhadap Minat Belajar Dan Hasil Belajar IPS Pada Peserta Didik Kelas VII Sekolah Menengah Pertama Kesuma Sari Denpasar".Tujuan dalam penelitian ini adalah:

1. Untuk mengetahui dan mendeskripsikan pengaruh model pembelajaran kooperatif tipe picture and picture terhadap hasil belajar IPS pada peserta didik kelas VII sekolah menengah pertama kesuma sari Denpasar. 
2. Untuk mengetahui dan mendeskripsikan pengaruh model pembelajaran kooperatif tipe picture and picture terhadap minat belajar IPS pada peserta didik kelas VII sekolah menengah pertama kesuma sari Denpasar.

3. Untuk mengetahui dan mendeskripsikan pengaruh antara model pembelajaran kooperatif tipe picture and picture terhadap minat belajar dan hasil belajar pada peserta didik kelas VII sekolah menengah pertama kesuma sari Denpasar.

\section{METODE}

Pada penelitian ini menggunakan jenis penelitian eksperimen semu atau quasi eksperiment. Penelitian ini bertujuan untuk mengetahui pengaruh model pembelajaran kooperatif tipe picture and picture terhadap minat belajar dan hasil belajar IPS pada peserta didik kelas VII sekolah menengah pertama kesuma sari Denpasar. Penelitian ini menggunakan metode penelitian eksperimen. Penelitian eksperimen adalah penelitian kuantitatif yang memenuhi semua persyaratan unutuk menguji hubungan sebab akibat dan korelasional yang menunjukkan hubungan antara dua variabel. Ciri utama dalam penelitian eksperimen adalah adanya pengontrolan [ada variabel dan pemberian perlakuan terhadap kelompok eksperimen. Menurut Suharsimi (2006: 207) penelitian eksperimen merupakan penelitian yang dimaksudkan untuk mengetahui ada tidaknya akibat dari "sesuatu" yang dikenakan pada subjek selidik.

Pada penelitian ini menggunakan jenis penelitian eksperimen semu atau quasi eksperiment. Hal ini dikarenakan penelitian tidak mungkin mengubah kelas dalam menentukan subjek atau kelas dalam penelitian ini, sehingga yang di random hanya kelas bukan individu di dalam kelas tersebut. Desain rancangan eksperimen pada penelitian ini menggunakan dua kelompok yaitu: kelompok ekperimen (eksperimen group) dan kelompok kontrol (control group). Populasi dalam penelitian ini adalah siswa kelas VII SMP Kesuma Sari Denpasar sebanyak 78 siswa yang terbagi ke dalam 3 kelas. Subjek penelitian adalah kelas VII yaitu kelas VII1 dan VII2 SMP Kesuma Sari Denpasar. Pengambilan sampel dilakukan dengan teknik Random Sampling yaitu suatu cara pengambilan sampel secara acak, dimana sampel yang diambil berdasarkan kelas, bukan individu.

Variabel pada penelitian ini yaitu:

1. Variabel bebas pada penelitian ini adalah model pembelajaran yaitu model pembelajaran koperatif tipe picture and picture.

2. Variabel terikat pada penelitian ini adalah minat belajar dan hasil belajar.

Dalam penelitian ini data yang dikumpulkan adalah data mengenai minat belajar, dan hasil belajar siswa setelah pembelajaran dengan menggunakan model pembelajaran kooperatif tipe picture and picture. Data minat belajar dikumpulkan dengan memberikan angket, sedangkan pengumpulan hasil belajar IPS pada siswa dengan model tes pilihan ganda.

Uji prasyarat instrument pada penelitian ini menggunakan uji validitas, uji realibilitas, uji tingkat kesukaran, uji daya beda Selanjutnya data-data yang diperoleh dianalisis secara statistik (1) memberikan skor dari angket minat bejar siswa dan posttest hasil belajar siswa, (2) menghitung rata-rata hasil posttest dan standar deviasi siswa, (3) menguji normalitas data, (4) menguji homogenitas varians, (5) menguji homoginitas matriks varians-kovarian, (6) menguji korelasi variabel terikat dengan uji multikolinieritas, (7) selanjutnya dilakukan pengujian hipotesis menggunakan Manova, dan (8) membuat kesimpulan.

\section{HASIL DAN PEMBAHASAN}

Data dalam penelitian ini dikelompokkan menjadi: 1) Minat Belajar yang dibelajarkan dengan model pembelajaran picture and picture, 2) Minat Belajar yang dibelajarkan dengan model pembelajaran konvensional, 3) Hasil Belajar IPS yang dibelajarkan dengan model pembelajaran picture and picture, dan 4) Hasil Belajar IPS yang dibelajarkan dengan model pembelajaran konvensional. Selanjutnya dilakukan perhitungan sentral dari masing-masing data untuk mencari mean, median, modus serta standar deviasi dari tiap-tiap kelompok data. 
Perhitungan pengukuran sentral (mean, median, modus) dan ukuran penyebaran data (standar deviasi).

Berdasarkan hasil analisis, rata-rata skor data Minat Belajar yang mengikuti model pembelajaran picture and picture adalah 82,17 berada pada interval $X \geq 75$. Sehingga berdasarkan tabel klasifikasi yang telah dibuat, diketahui bahwa data-data Minat Belajar siswa yang mengikuti model pembelajaran picture and picture termasuk pada klasifikasi sangat tinggi. rata-rata skor data Minat Belajar yang mengikuti model pembelajaran konvensional adalah 77,87 berada pada interval $X \geq 75$. Sehingga berdasarkan tabel klasifikasi yang telah dibuat, diketahui bahwa data-data Minat Belajar siswa yang mengikuti model pembelajaran konvensional termasuk pada klasifikasi sangat tinggi. rata-rata skor data Hasil Belajar IPSyang mengikuti model pembelajaran picture and picture adalah 84,81 berada pada interval $X \geq 75$. Sehingga berdasarkan tabel klasifikasi yang telah dibuat, diketahui bahwa data-data Hasil Belajar IPS yang mengikuti model pembelajaran picture and picture termasuk pada klasifikasi sangat tinggi.

Adapun rata-rata skor data Hasil Belajar IPSyang mengikuti model pembelajaran konvensional adalah 73,6 berada pada interval 58,33 $\leq X<75$. Sehingga berdasarkan tabel klasifikasi yang telah dibuat, diketahui bahwa data-data Hasil Belajar IPSyang mengikuti model pembelajaran konvensional termasuk pada klasifikasi tinggi. Berdasarkan hasil analisis data Minat Belajar siswa yang mengikuti model pembelajaran picture and picture dan model pembelajaran konvensional terlihat rata-rata nilai siswa yang mengikuti model pembelajaran picture and picture lebih tinggi dibandingkan siswa yang mengikuti model pembelajaran konvensional. Nilai tersebut yaitu 82,17 (klasifikasi sangat tinggi) pada model pembelajaran picture and picture dan 77,87 (klasifikasi sangat tinggi) pada model pembelajaran konvensional. Berdasarkan hasil analisis data Hasil Belajar IPS siswa yang mengikuti model pembelajaran picture and picture dan model pembelajaran konvensional terlihat rata-rata nilai siswa yang mengikuti model pembelajaran picture and picture lebih tinggi dibandingkan siswa yang mengikuti model pembelajaran konvensional. Nilai tersebut yaitu 84,81 (klasifikasi sangat tinggi) pada model pembelajaran picture and picture dan 73,6 (klasifikasi tinggi).

\section{Uji Normalitas}

Uji normalitas untuk mengetahui apakah sebaran data sampel yang akan dianalisis berdistribusi normal atau tidak. Kelompok yang akan diuji normalisasinya berjumlah dua kelompok, yang terdiri dari kelompok siswa yang diberi perlakuan menggunakan model Example Non Example (kelompok eksperimen) dan kelompok siswa yang diberi perlakuan menggunakan model konvensional (kelompok kontrol).

Hasil perhitungan uji normalitas yaitu sebagai berikut.

1. Untuk data Minat Belajar pada kelas eksperimen memiliki nilai Kolmogorov-smirnov 0,121 dengan nilai signifikansi 0,200. Nilai statistik menunjukkan angka signifikansi lebih besar dari 0,05, sehingga dapat dikatakan bahwa data Minat Belajar kelas eksperimen berdistribusi normal.

2. Untuk data Minat Belajar pada kelas kontrol memiliki nilai Kolmogorov-smirnov 0,160 dengan nilai signifikansi 0,097. Nilai statistik menunjukkan angka signifikansi lebih besar dari 0,05, sehingga dapat dikatakan bahwa data Minat Belajar kelas kontrol berdistribusi normal.

3. Untuk data Hasil Belajar IPS pada kelas eksperimen memiliki nilai Kolmogorov-smirnov 0,102 dengan nilai signifikansi 0,200. Nilai statistik menunjukkan angka signifikansi lebih besar dari 0,05, sehingga dapat dikatakan bahwa data Hasil Belajar IPS kelas eksperimen berdistribusi normal.

4. Untuk data Hasil Belajar IPS pada kelas kontrol memiliki nilai Kolmogorov-smirnov 0,116 dengan nilai signifikansi 0,200. Nilai statistik menunjukkan angka signifikansi lebih besar 
dari 0,05 , sehingga dapat dikatakan bahwa data Hasil Belajar IPS kelas kontrol berdistribusi normal.

\section{Uji Homogenitas Varians}

Uji homogenitas varians antar kelompok ini dapat dilakukan dengan menggunakan statistik levene. Kriteria pengujian yang digunakan adalah data yang memiliki varians yang sama (homogen) jika angka signifikansi yang dihasilkan lebih besar dari 0,05. Dari hasil uji homogenitas tampak bahwa nilai signifikansi untuk data Minat Belajar 0,389 dan Hasil Belajar IPS siswa 0,930. Hal ini menunjukkan bahwa signifikansinya lebih besar dari 0,05, dengan demikian data penelitian diatas adalah homogen.

\section{Uji Homogenitas Matriks Varians}

Uji homogenitas matriks varian-kovarians antar variabel dependen menggunakan Box's Test Equality Covariance Matrices dengan bantuan program SPSS 23.0 for windows. Uji homogenitas dilakukan terhadap kelompok data Minat Belajar dan Hasil Belajar IPS siswa secara bersama-sama menggunakan uji Box's $M$. Berdasarkan hasil uji Box's $M$ kesamaan matriks varians-kovarians secara simultan menghasilkan angka signifikan sebesar 0,811 lebih besar dari nilai $\alpha=0,05$. Hal ini berarti bahwa matriks varians pada variabel Minat Belajar dan Hasil Belajar IPS siswa adalah homogen.

\section{Uji Multikolinieritas}

Selain uji normalitas dan homogenitas, salah satu syarat yang harus dipenuhi dalam analisis Manova adalah kedua variabel tidak berkorelasi tinggi.Uji Multikolinieritas digunakan untuk mengetahui apakah terjadi hubungan atau korelasi yang cukup tinggi antar variabel terikat Berdasarkan hasil uji multikolinieritas menunjukkan nilai tolerance yang dihasilkan 0,957 lebih besar dari 0,1 dan nilai VIF (variance inflation factor) = 1,045 lebih kecil dari 10. Sehingga dapat disimpulkan bahwa antara variabel tidak terdapat masalah multikolinieritas atau tidak terjadi hubungan/korelasi yang cukup tinggi antar variabel Minat Belajar dan Hasil Belajar IPS.

\section{UJI HIPOTESIS \\ UJI HIPOTESIS 1}

Hipotesis yang diuji yaitu Ho, di mana kriteria menyatakan bahwa Ho ditolak apabila taraf signifikansi untuk Pillai's Trace, Wilk's Lambda, Hotelling's Trace, dan Roy's Largest Root lebih kecil dari 0,05. Berdasarkan Tabel 4.10 diperoleh angka statistik F sama dengan 10,067 dan angka signifikansi 0,000 kurang dari 0,05 untuk Pillai's Trace, Wilk's Lambda, Hotelling's Trace, dan Roy's Largest Root. Jadi hipotesis null (Ho) ditolak dan dapat disimpulkan bahwa terdapat perbedaan Minat Belajar dan Hasil Belajar IPS siswa antara kelompok siswa yang belajar dengan model pembelajaran picture and picture dengan kelompok siswa yang belajar dengan model pembelajaran konvensional.

\section{UJI HIPOTESIS 2}

Hipotesis 2 yang diuji dengan test of between-subjects effects yaitu $\mathrm{Ho}$, di mana kriteria menyatakan bahwa Ho ditolak apabila taraf signifikansi $F$ lebih kecil dari 0,05 . Berdasarkan Tabel 4.11 diperoleh angka statistik $F$ sama dengan 7,355 dan angka sig. 0,009<0,05. Jadi hipotesis null (Ho) ditolak dan dapat disimpulkan bahwa terdapat perbedaan Minat Belajar siswa antara kelompok siswa yang belajar dengan model pembelajaran picture and picture dengan kelompok siswa yang belajar dengan model pembelajaran konvensional. Adapun rata-rata Minat Belajar kelompok siswa yang belajar dengan model pembelajaran picture and picture yaitu 82,17 lebih besar dibandingan dengan kelompok siswa yang belajar dengan model pembelajaran konvensional yaitu 77,87.

\section{UJI HIPOTESIS 3}


Hipotesis 3 yang diuji dengan test of between-subjects effects yaitu $\mathrm{Ho}$, di mana kriteria menyatakan bahwa Ho ditolak apabila taraf signifikansi $F$ lebih kecil dari 0,05 . Berdasarkan Tabel 4.11 diperoleh angka statistik F sama dengan 14,135 dan angka sig. 0,000<0,05. Jadi hipotesis null (Ho) ditolak dan dapat disimpulkan bahwa terdapat perbedaan Hasil Belajar IPS siswa antara kelompok siswa yang belajar dengan model pembelajaran picture and picture dengan kelompok siswa yang belajar dengan model pembelajaran konvensional. Adapun ratarata Hasil Belajar IPS kelompok siswa yang belajar dengan model pembelajaran picture and picture yaitu 84,81 lebih besar dibandingan dengan kelompok siswa yang belajar dengan model pembelajaran konvensional yaitu 73,6.

Berdasarkan tabel hasil uji tukey tampak perbedaan skor rata-rata Minat Belajar antara kelompok Model pembelajaran picture and picture dan kelompok pembelajaran konvensional adalah $\Delta \mu=[\mu-\mu]$ sebesar 4,31 nilai $Q$ hitung 3,69 lebih besar dari $Q$ tabel 2,91. Jadi, dapat disimpulkan bahwa pada taraf signifikansi 0,05 skor rata-rata Minat Belajar siswa pada kelompok Model pembelajaran picture and picture dan pembelajaran konvensional berbeda secara signifikan. Nilai rata-rata Minat Belajar pada kelompok Model pembelajaran koperatif tipe picture and picture 82,17 lebih besar dibandingkan pembelajaran konvensional 77,87. Artinya Model pembelajaran picture and picture lebih baik dibandingkan pembelajaran konvensional untuk meningkatkan Minat Belajar siswa.

\section{PENUTUP}

Berdasarkan analisis dan pembahasan seperti yang telah dipaparkan pada bagian sebelumnya, maka dapat disimpulkan beberapa hal sebagai berikut.

1. Terdapat perbedaan Minat Belajar dan Hasil Belajar IPS siswa antara kelompok siswa yang belajar menggunakan model pembelajaran picture and picture dengan kelompok siswa yang belajar dengan menggunakan model pembelajaran konvensional. Hal tersebut berdasarkan pada hasil analisis Manova yang memperoleh angka statistik $\mathrm{F}$ sama dengan 10,067 dan angka signifikansi 0,000 kurang dari 0,05 untuk Pillai's Trace, Wilk's Lambda, Hotelling's Trace, dan Roy's Largest Root.

2. terdapat perbedaan Minat Belajar siswa antara kelompok siswa yang belajar menggunakan model pembelajaran picture and picture dengan kelompok siswa yang belajar dengan menggunakan model pembelajaran konvensional. Hal tersebut berdasarkan pada hasil analisis angka statistik $\mathrm{F}$ sama dengan 7,355 dan angka sig. 0,009<0,05.

3. terdapat perbedaan Hasil Belajar IPS siswa antara kelompok siswa yang belajar menggunakan model pembelajaran picture and picture dengan kelompok siswa yang belajar dengan menggunakan model pembelajaran konvensional. Hal tersebut berdasarkan pada hasil analisis angka statistik $F$ sama dengan 14,135 dan angka sig. 0,000<0,05.

Berdasarkan hasil penelitian di atas, maka kepada guru disarankan menggunakan model pembelajaran koperatif tipe picture and picture sebagai alternatif model pembelajaran selama proses pembelajaran dengan tetap memperhatikan sintak-sintak model pembelajaran. Guru diharapkan mengurangi penerapan model pembelajaran langsung/konvensional.

\section{DAFTAR PUSTAKA}

Trianto. 2009. Model-Model Pembelajaran Inovatif Berorientasi Konstruktivistik. Jakarta : Prestasi Pustaka.

Susanto, A. 2012. Teori Belajar dan Pembelajaran. Jakarta: Kencana Prenadamedia Group

Suwatra, dkk. 2007. Modul Belajar dan Pembelajaran. Singaraja: Undiksha.

Susanto (2012:185) mengatakan 
Susanto, A. 2012. Teori Belajar dan Pembelajaran. Jakarta: Kencana Prenadamedia Group Isjoni. 2012. Cooperatif Learning. Bandung: Alfabeta

Susanto, A. 2012. Teori Belajar dan Pembelajaran. Jakarta: Kencana Prenadamedia Group

Marhaeni, A.A.I.N. 2012. Evaluasi Pendidikan. Singaraja: Undiksha

Arikunto, Suharsimi. 2006. Prosedur Penelitian Suatu Pendekatan Praktik. Jakarta: Rineka Cipta 